\section{NACIÓN E IDENTIDAD EN LOS IMAGINARIOS VISUALES DE LA ARGENTINA. SIGLOS XIX Y XX}

\author{
Mariana Giordano \\ IIGHI-CONICET/UNNE
}

\section{NATION AND IDENTITY TO THE VISUAL IMAGINARIES IN ARGENTINA AT 19th AND 20th CENTURIES}

\begin{abstract}
The construction of symbolic regards and itineraries referring on the "Nation" in Argentina begins in the years following the emancipation of the Rio de la Plata in 1810. The eyes of foreign and argentines artists will focus on the nineteenth century on representations of the Pampa, the indigenous and gaucho as symbols of identity, forming an imaginary that is updated in different contexts and using differents art languages in 19th and 20th century. Cosmopolitism and nationalism are two lines through which transmitted the positions, debates and visions on the Argentine identity, forging an hegemonic imaginary focused on what was produced and enshrined in Buenos Aires, with little or no participation from regional productions.
\end{abstract}

KEY WORDS: Imaginary; nacionalism; identity; cosmopolitism; Argentina; 19th and 20th centuries.

\section{INTRODUCCIÓN}

Aventurarnos a reconstruir los imaginarios de Nación en las artes visuales de la Argentina requiere considerar tantas caras del prisma social, étnico, artístico-cultural y político que a nuestro juicio, sólo quedarán esbozadas parcialmente en este trabajo. Asimismo, ello supone en otros términos, la posibilidad de continuar la discusión en torno de las memorias visuales instauradas a partir de una iconografía específica y viceversa, intervenir en el debate acerca de la canonización de cierta iconografía a partir de una memoria local, regional, nacional como así también de las manifestaciones de arte "consagrado" y de producciones "periféricas" (consideradas según diferentes apelativos como artesanales, kitsch o populares).

Para ello quizás resulte pertinente partir de una concepción dinámica de "imaginario", concepción que nos posi-
RESUMEN: La necesidad de construir referentes e itinerarios simbólicos sobre la "Nación" en la Argentina comienza en los años que siguieron a la emancipación del Río de la Plata en 1810. La mirada de artistas extranjeros y argentinos se centrará en gran parte del siglo XIX en representaciones de la Pampa, el indígena y el gaucho como símbolos identitarios, constituyendo un imaginario que se reactualizará en distintos contextos y acudiendo a diferentes lenguajes a lo largo de los siglos XIX y XX. Cosmopolitismo y nacionalismo se constituyen en dos ejes por donde transitarán las posturas, debates y visiones sobre la identidad argentina, forjando un imaginario hegemónico centrado en lo producido y consagrado en Buenos Aires, con poca o ninguna participación de producciones o referentes regionales.

PALABRAS CLAVE: Imaginario; nacionalismo; identidad; cosmopolitismo; Argentina; siglos XIX y XX.

bilite observar la vitalidad histórica de las creaciones de los sujetos, en nuestro caso, de las producciones visuales, como así también el uso social de las representaciones y de los símbolos. 0 en otros términos, vislumbrar su eficacia política, eficacia que dependerá del grado de reconocimiento social alcanzado en cierta colectividad o grupo social de la Argentina del siglo XIX y parte del XX.

Baczko señala que es por medio del imaginario que se pueden alcanzar las aspiraciones, los miedos y las esperanzas de un pueblo. En él, las sociedades esbozan sus identidades y objetivos, identifican sus enemigos y organizan su pasado, presente y futuro. Se trata de un lugar estratégico en que se expresan conflictos sociales y mecanismos de control de la vida colectiva. El imaginario social se expresa en ideologías y utopías y también por símbolos, alegorías, rituales y mitos; estos elementos plasman visiones de mundo, modelan conductas y estilos de vida, en movimientos 
continuos o discontinuos de preservación de la orden vigente o de introducción de cambios (Baczko, 1984, 54).

¿Qué ocurre cuando el/los imaginarios que se construyen apuntan a identificar colectivamente a una sociedad con una idea de Nación que emerge, da forma, se reformula, legitima y consolida también históricamente? Dichos imaginarios dejan sus huellas en paquetes visuales y textuales que en ocasiones abarcan flujos más amplios, por lo tanto: ¿qué vínculos tienen los imaginarios de Nación construidos en la Argentina en relación a los imaginarios de Nación en Latinoamérica? Por otro lado, si la identidad nacional es un "... proceso de socialización mediante el cual los individuos aceptan una serie de normas y valores como propios y los interiorizan como cauce de su comportamiento social..." (Pérez Vejo, 2003, 295), ¿cuál es la relación entre identidad y Nación en las producciones visuales en la Argentina?, 0 tal vez, ¿existe una identidad construida visualmente 0 identidad(es) complementarias y/o contradictorias? Éstos son sólo algunos de los interrogantes que guiarán el presente trabajo, a través del análisis de la producción en pintura y escultura conmemorativa, aunque también abordaremos en menor medida la fotografía y el cine, desde la emancipación del Río de la Plata en 1810 hasta los orígenes del Estado peronista en la década de 1940.

Para ello nos apoyamos en el planteo de Bertoni, quien ha analizado la construcción de la nacionalidad en la Argentina siguiendo los itinerarios políticos y culturales, y señalando la emergencia de dos momentos significativos: el primero de ellos luego de 1810, cuando la nacionalidad estaba vinculada a la creación y consolidación de un Estado independiente y el segundo, en el contexto de la política liberal de 1880, cuando la afluencia de inmigración masiva y el inicio de una nueva etapa en la formación de las naciones y las nacionalidades en Europa dieron impulso a un amplio movimiento de carácter nacional. Ello derivó en dos posturas contrapuestas: un cosmopolitismo partidario de una actitud inclusiva que partía de la heterogeneidad del cuerpo social y un nacionalismo que se oponía a esta inclusión, postulando la homogeneidad cultural y la "raza" nacional (Bertoni, 2001). En las páginas que siguen trataremos de ver entonces los modos en que en estos dos momentos emerge y se consolida una "comunidad imaginada" (Anderson, 1990), y cuáles son los itinerarios simbólicos trazados entre ambos momentos como hilos conductores de este imaginario de Nación.

\section{LAS IMÁgenes del "deSPERTAR de la NACIÓN"}

La necesidad de conformar un imaginario visual se desarrolló en forma paralela a otras estrategias políticas y discursivas que apuntaban a construir la Nación y la identidad nacional.

Los años que siguieron a la emancipación argentina de 1810 se caracterizaron por campañas libertadoras de pueblos vecinos, luchas civiles, anarquía, intentos de lograr la constitucionalidad, enfrentamientos entre facciones (unitarios y federales), constitución de una nueva sociedad. En medio de ello las celebraciones anuales de las fiestas patrias, donde "... el estado celebra sus héroes, sus gestas, sus simbolos y al hacerlo convoca a un consenso alrededor de su legitimidad" (Munilla Lacasa, 1995, 154). En el primer aniversario de la Revolución de Mayo de 1810, fue la Pirámide de Mayo la empresa monumental que inició el camino de los hitos conmemorativos, que tuvo su continuidad en el monumento que recordara la batalla de Salta en 1813. La fiesta fue asimismo consagrada pictóricamente años después con la obra del francés Carlos Pellegrini "Fiestas Mayas" (ca. 1841), donde se incluian todos los símbolos que la nueva Nación había logrado consolidar.

En la búsqueda de esta identidad nacional -cuando en realidad continuaban en este contexto culturas locales y regionales diferenciales-, el nacionalismo artístico se evidenció en dos planos: por un lado, un "nacionalismo oficial" (Pérez Vejo, 2003) que se orientó hacia los encargos artísticos para retratar los héroes que el proceso de emancipación e independencia había brindado y a dejar testimonios visuales de los hechos históricos que actuaban como hitos del origen de la Nación, y por otro lado, un "nacionalismo no oficial", que se reflejó en la obra de los artistas viajeros y los primeros artistas argentinos, donde la mirada sobre el paisaje y las costumbres intentarán sintetizar la identidad de la Argentina.

\section{LA DELINEACIÓN DEL HÉROE NACIONAL}

Todas las nuevas naciones americanas que empezaron a constituirse alrededor de 1810 encontraron como urgencia la necesidad de contar con héroes que actuaran como referentes morales, políticos y militares. Ésto también ocurrió 
en la Argentina, y particularmente en Buenos Aires donde surgen los primeros retratos litografiados de San Martín (1818) y Belgrano (1818, 1819 y 1821), realizados todos ellos por el platero, grabador y maestro de dibujo correntino residente en Buenos Aires Manuel Pablo Núñez de Ibarra. El primero respondía a una convocatoria de la Asamblea, que había propuesto la realización de una lámina que recordara las victorias de San Martín en Chacabuco y Maipú, donde se señalaban los símbolos que esta lámina debía contener (Munilla Lacasa, 1999, 254-255). Ello estaría poniendo en evidencia la intervención oficial en la delineación de la imagen del héroe y del contexto en que este debía presentarse. Los retratos de San Martín y Belgrano de Núñez de Ibarra, quien también retrató al presidente Bernardino Rivadavia, fueron utilizados de modelo por Théodore Gericault para retratar a estos héroes y para la realización de las representaciones de las batallas de Maipú y Chacabuco.

Si bien estos intereses en la representación de la imagen del héroe constituyeron una urgencia para la naciente Nación, las estatuas ecuestres de ambos héroes se postergaron hasta 1862 y 1872 respectivamente, y fue en Buenos Aires donde se realizaron primero, para repetirse el modelo iconográfico en diversas provincias.

\section{PAMPA, INDIOS Y GAUCHOS: LOS ORÍGENES DE LOS IMAGINARIOS VISUALES NACIONALES}

Otra de las vertientes en que se manifestó el imaginario de Nación en la Argentina responde a un nacionalismo que estuvo ligado a la concepción de unificación del territorio y que se justificó en el concepto de "desierto"1 con que el Estado nominaba a las regiones en poder de los indígenas: es el espacio vacio, en el que señorea la figura del ombú, que comienza a ser ocupado por las escenas camperas y los itinerarios de viaje, de cruce, de esa inmensidad. Este imaginario se evidenció en la mirada de los artistas viajeros, y se centró en representar la identidad natural en la pampa y el drama social que en ella se vivía, sintetizando el conflicto cultural en el que participan gauchos, indígenas y cautivas. La mayoría de estos artistas eran extranjeros y revelaron a través de sus obras la "mirada desde afuera", la que junto a la producción de los primeros pintores argentinos constituyeron la iconografía inicial de lo que por gran parte del siglo XIX se constituiría en el núcleo del imaginario nacional. La Nación tenía entonces un espacio natural inconmensurable, donde se debatían las fuerzas sociales que configuraban su dimensión humana: el escenario era el "desierto" y sus ocupantes simbolizaban el discurso oficial de civilización-barbarie que la generación del ochenta tomó como eje para la ocupación y conquista armada del desierto.

Los artistas viajeros veían a los argentinos "... perdidos en la infinitud. Revoleando armas y boleadoras para atrapar algo inapresable y enemigo que se escapaba del interior del hombre. Pampa de hijos de indios que perseguian a sus ancestros para arrancárselos de la memoria y la piel..." (Dujovne Ortiz, 2001, 9).

El francés Raymond Quinsac Monvoisin, el bávaro Johann Moritz Rugendas, el brasileño de origen francés Juan León Pallière y los argentinos Carlos Morel y Prilidiano Pueyrredón (fig. 1) vieron en la representación del gaucho, su vida, anhelos y costumbres, su participación en las contiendas civiles, el símbolo de lo nacional, a la vez que Rugendas, impresionado por la novela "La cautiva" de Esteban Echeverría, también dio rienda suelta a su imaginación en las escenas de malones indígenas y raptos de mujeres blancas en su obra "El rapto de la cautiva" (1845, Museo Nacional de Bellas Artes, Buenos Aires), tema recurrente en la iconografía nacional, principalmente desde la década de 1870 hasta fines de siglo, cuando Juan Manuel Blanes pinta "Malón" y "Rapto de una blanca"; escena y escenario que se reformulan también con "La vuelta del malón", de Ángel Della Valle, una de las obras-símbolo del concepto decimonónico argentino de "civilización-barbarie".

De tal forma, "durante el siglo XIX el paisaje pampeano constituyó un todo inescindible con el drama que se desarrollaba en él. Este, que podría resumirse como el drama de la conquista, presenta dos aspectos: uno consiste en la epopeya cotidiana de atravesar y poblar el desierto. Los ranchos, las carreteras señalan la proeza de la presencia humana en esas soledades. El otro es el enfrentamiento con el indio por la posesión de la tierra" (Malosetti Costa y Penhos, 1999, 197).

Si la pampa era el símbolo del "nacionalismo natural" para artistas viajeros y nacionales (como el caso de Prilidiano Pueyrredón en cuya obra esa pampa es inconmensurable, 


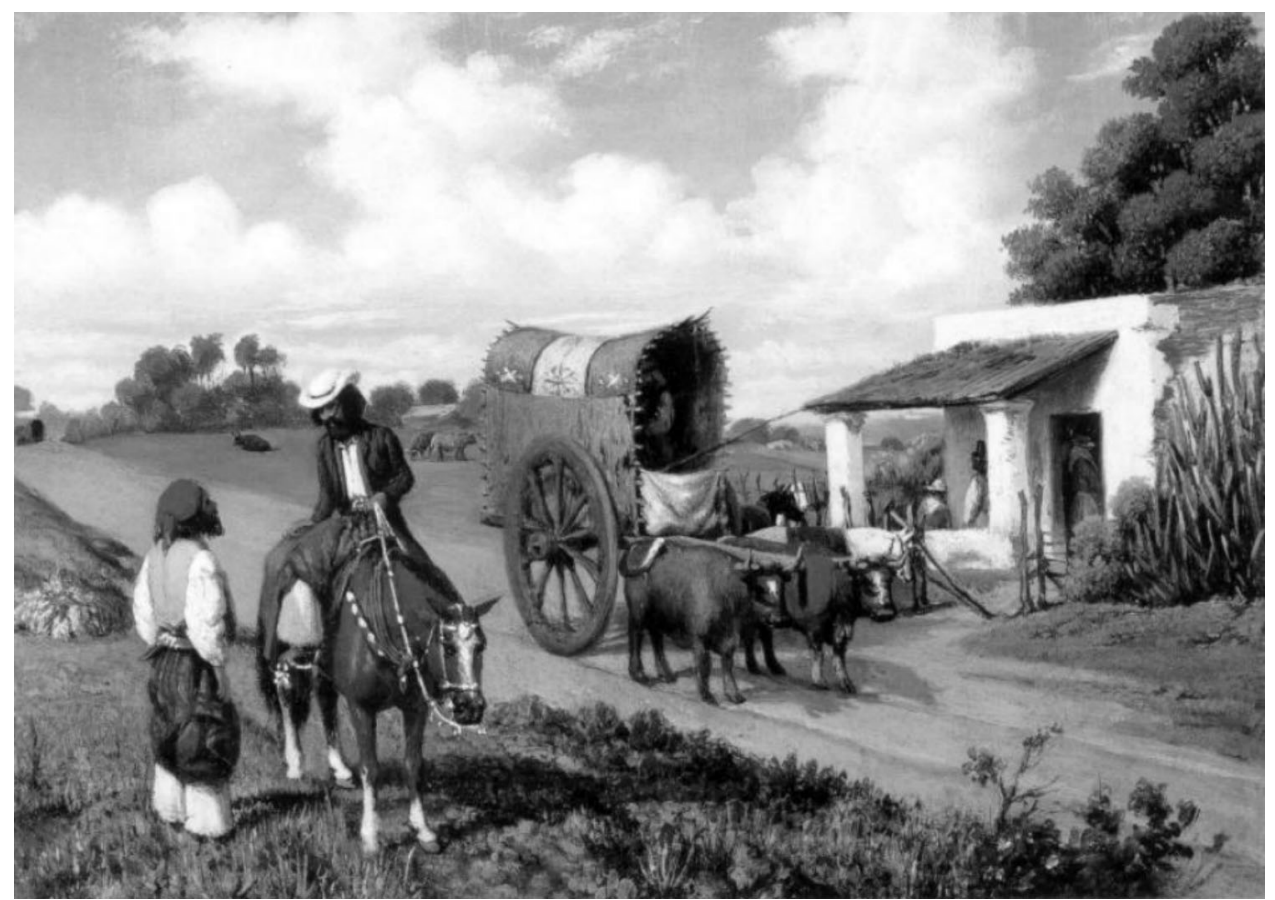

un mar de tierra que las carretas debian atravesar), el gaucho y el indígena eran los actores sociales en ese paisaje.

No obstante, los artistas también propusieron una contracara para este imaginario social y cultural: los retratos de la élite porteña, sus lugares de encuentro social y el nuevo paisaje urbano que ofrecía la ciudad de Buenos Aires, convertida en eje y referente de los discursos y contradiscursos visuales. Si bien varios artistas recorrieron el interior de la Argentina, Buenos Aires, la colonia que se transformaba en ciudad, operaba de contraste, de referente "civilizado" a partir del cual se visibilizaba el resto de la naciente nación. De esta manera, se atribuía una identidad a "los otros" (gauchos e indígenas), considerándolos como objetos exóticos del drama de la pampa, y diferenciándolos de la identidad de la élite, que se correspondía con el paisaje urbano y la vida social de Buenos Aires.

El despertar de la Nación ya tenía su panteón de héroes -aun en germen- y sus símbolos: pampa, indígena, gaucho y una élite privilegiada que se perfilaba -tanto en las artes plásticas como en otras manifestaciones culturales- como la guía para descubrir los senderos que construirian la "Nación Argentina".

\section{LO OUE QUEDA EN LOS BORDES: PINTURA REGIONAL E IMAGINERÍA POPULAR}

La pintura y la escultura académica de las grandes ciudades, en particular Buenos Aires, fue la que delineó el imaginario de Nación en la Argentina, en el que se mezclaron ensoñaciones y deseos, intereses sociales con imágenes de una fuerte carga sentimental. Ello estaría poniendo en evidencia los modos de construcción de identidades nacionales hegemónicas y homogeneizantes que desdibujan, ocultan o dejan de lado las particularidades regionales y locales.

El interior del país también recibió la llegada de algunos artistas viajeros y otros locales, en su mayoría autodidactas, que a partir de la enseñanza de los primeros, desarroIlaron principalmente la pintura retratística. 
Asi continuaron o surgieron producciones regionales que fueron "vencidas" en esta "contienda de imágenes", como también los caudillos del interior fueron vencidos por las armas de Buenos Aires. Fueron estos caudillos algunos de los sujetos de representación de la pintura regional, muchos de ellos anónimos o realizados por pintores provincianos, en particular en la zona del litoral argentino. Muchos de ellos presentan figuras ecuestres de caudillos litoraleños, gauchos-soldados como lo hiciera Morel en Buenos Aires, retratos populares y escenas de batallas. Estas pinturas populares-federales "... son la expresión de una cuestión política: la organización de las estructuras militares que dieron sustento al caudillismo y las autonomías de los Estados provinciales. Refieren a una red jerárquica y territorial, que es a la vez urbana y rural..." (Amigo, 2003 , 274). Por consiguiente, estas escenas gauchescas y populares, no deben ser vistas como meras escenas de costumbre, sino como una expresión ideológico-política de aquello que también debía constituir la Nación, pero que finalmente, quedaron olvidadas. Asimismo, el antiacademicismo de estas expresiones y su cercanía al arte popular transmiten una afirmación de lo antieuropeo que caracterizaba al régimen federal.

Por otro lado, la iconografía religiosa heredera de la época de la colonia, continuó teniendo una producción activa en las décadas posteriores a la independencia, en particular en la producción de imágenes religiosas en la región de las antiguas misiones jesuiticas y en el Noroeste argentino. Y más aún, las obras resultantes de la imaginería popular y la platería, de larga tradición en provincias como Corrientes $^{2}$, fueron aquellas visibilidades ocultas en la consagración del arte nacional que continuaron teniendo vigencia, -aunque en claro declive- hasta mediados del siglo XX. Asimismo, la producción de retablos populares y de imágenes devocionales en el Noroeste argentino son ejemplos de interés, pero que, al responder a visiones de mundo locales no fueron consideradas dentro de los elementos a constituir un imaginario nacional. Si bien es cierto que la historiografía del arte del siglo XX ha reproducido este ocultamiento ${ }^{3}$, fue en los orígenes de la Nación argentina en que se instauró el arte académico y consagrado en Buenos Aires, que representa el poder social y económico de una burguesía que a la vez comienza a consolidarse en el terreno político y que legitima su poder en la construcción de una cultura nacional soslayando las culturas locales.
Esto es parte de lo que queda en los bordes del imaginario de Nación que se construye en la Argentina.

\section{Nación, Estado e identidad. Hacia la consolidación DE REFERENTES IDENTITARIOS}

Historia e iconografía irán de la mano en el proceso de construcción de epopeyas, hechos relevantes y figuras ilustres que protagonizaron los sucesos que constituyeron "la Nación" (Gutiérrez y Gutiérrez Viñuales, 2006). De ahí la consolidación de una iconografía que documentara visualmente esos aspectos de un pasado no muy lejano y que legitimara los hechos contemporáneos que la élite dirigente encauzaba.

La galería de retratos de "notables" que heredara los realizados en la época post revolucionaria había tenido continuidad en la década de 1850, cuando el Estado de Buenos Aires se encontraba separado de la Confederación Argentina. El primero, "... se asumió como heredero de la tradición de Mayo y de las reformas rivadavianas, y por ello su imagen predilecta fue la Libertad-República. La Confederación, a su vez, sostuvo un discurso federalista, y prefirió acompañar la imagen de la República por la Ley y la Justicia, para afirmar la legitimidad constitucional del gobierno, sin olvidar la Gloria..." (Amigo, 1999b, 12). Fue en este contexto en el que se articuló la historiografía con el panteón de las "celebridades argentinas", en palabras de Bartolomé Mitre: San Martín, Belgrano, Rawson, Rivadavia, Varela, Lavalle, Alvear, Sarmiento, Alsina, Mármol, Calvo, serán algunos de los retratos que integrarán este panteón de los héroes y que los ensayos históricos justificarán en el discurso escrito ${ }^{4}$. El campo de las celebridades pretendía ser más amplio que los iniciales padres de la patria del panteón nacional de la iconografía previa. Así nos encontramos con militares, políticos, hombres de letras y pensadores, que a través de un discurso homogeneizador eran presentados como los depositarios de la memoria nacional. Fue este discurso escrito y visual el que se retomará una vez lograda la unificación del país y consolidada Buenos Aires como capital ${ }^{5}$, como modo de sentar las bases del Estado nacional.

Las últimas décadas del siglo XIX marcaron en Buenos Aires la transformación progresiva de la ciudad en lo edilicio 
y social, lo que coadyuvó a las transformaciones culturales. La ciudad se consolidó como una de las grandes capitales latinoamericanas, que buscaba espejarse en Paris, y donde vivian hombres ilustrados, muchos de los cuales se convirtieron en coleccionistas de arte. La clase tradicional y patricia compartía con la clase dirigente de la generación del ' $80^{6}$, la lucha contra el "salvajismo" efectivizada en las campañas armadas contra los indígenas que habitaban grandes extensiones de tierras en la pampa, Patagonia y Chaco. Se soñaba con el progreso como símbolo de producción y grandeza, propiciando la llegada de inmigración europea, aunque también se la vio con miedo y recelos ante el paulatino cambio del panorama social que la inmigración masiva significó.

Ya consolidada en el poder la élite porteña, la iconografía que siguió este nacionalismo visual oficial, además de consolidar la iconografía de las "celebridades" proyectándolas a todo el país, retomó el imaginario de la pampa y el gaucho que se había desarrollado en las décadas anteriores, vinculando ambos tópicos al tema de la conquista del desierto. Dos obras se convierten en paradigmas visuales de esta época: la "Ocupación militar del Río Negro, 1879", conocida como "Campaña al desierto del General Julio A. Roca", de Juan Manuel Blanes (1896, Museo Histórico Nacional) (fig. 2) y la ya mencionada "La vuelta del malón" de Ángel Della Valle (1892, Museo Nacional de Bellas Artes). La primera, encargada por el Estado nacional al pintor uruguayo admirado por la intelectualidad argentina por realizar obras de fuerte contenido documental-histórico, es una enorme tela que presenta similitudes con una fotografía del álbum de Moreno y Encina cuando integraron la expedición científica que acompañó a las campañas militares $^{7}$. La obra de Blanes presenta un primer plano triunfal de la alta jerarquía militar a caballo: a un costado se encuentra un grupo de indígenas evangelizados y la cautiva redimida junto al capellán del ejército, mientras al otro costado se representan los científicos y marinos que integraron la expedición; sintetiza asi el poder de Roca, su control sobre la situación del indígena y la "incorporación del desierto", pero también la capacidad de "solución" del "problema indígena" donde no se advierte el enfrentamiento, sino la pasividad y el sometimiento. Sin duda, el realismo y detallismo al que acude Blanes -que discutió con Roca diversos aspectos de la composición, los personajes, uniformes, monturas, etc.- tiene un fin pedagógico muy claro; asimismo, muchos de los retratados no coinciden con el tiempo y lugar de la escena, pero fueron quienes tuvieron un papel destacado en las campañas realizadas. La obra repite así la iconografía de las "entradas triunfales" que la pintura ha reproducido a lo largo de la historia del arte occidental, desde una actitud documentalista y condescendiente con los hechos representados, sin que emerja ningún índice del dramatismo que estas campañas supusieron para la población indígena. Esa entrada triunfal no es a una ciudad, sino que supone la puerta abierta a la ocupación de grandes extensiones de tierra por parte del Estado Nacional.

La otra pintura a la que hemos hecho referencia, "La vuelta del malón" de Della Valle, fue expuesta en una vidriera de la calle Florida de Buenos Aires: un malón indígena, en el escenario de la inmensidad pampeana, huye a caballo tras haber profanado una iglesia y capturado a una mujer blanca. La obra sintetizaba el discurso oficial de "salvajismo vs. civilización", encontrando visualmente los elementos legitimadores de ese discurso y de la acción armada contra el indígena, convertido en el depositario de los males que suceden en la pampa ${ }^{8}$.

La importancia de ambas obras no sólo reside en su vinculación con el discurso político y la ideología de la época, sino también por la circulación que ambas imágenes han tenido en diferentes publicaciones de décadas posteriores. En particular, la obra de Blanes -con un recorte que enfoca la escena central-, tiene una circulación actual como ilustración de los billetes de $\$ 100$ que el Estado argentino imprime, con el epígrafe "Conquista al desierto". La pintura de Della Valle también ha ilustrado libros históricos y hasta tapas de discos de tango ${ }^{10}$.

Desde la fotografía se completa este universo visual sobre el indígena y el "desierto": las imágenes de las campañas militares al sur, de indígenas sometidos e integrando en algunos casos contingentes armados del ejército argentino, o posando en estudios fotográficos de Buenos Aires, ya sea siguiendo los parámetros formales del retrato burgués 0 como un "primitivo" que ha dejado de ser temeroso y que se convierte en un objeto exótico. De tal forma, la figura del indígena se encuentra en este momento en un lugar confuso en cuanto a su papel en el panteón de "lo nacional": por un lado, es el personaje peligroso y demoníaco que hay que vencer (numerosos textos oficiales y periodísticos se orientaban en tal sentido), mientras que hacia 
2. Juan Manuel Blanes, Ocupación militar del Río Negro, 1879 (det.), 1896. Museo Histórico Nacional, Buenos Aires.

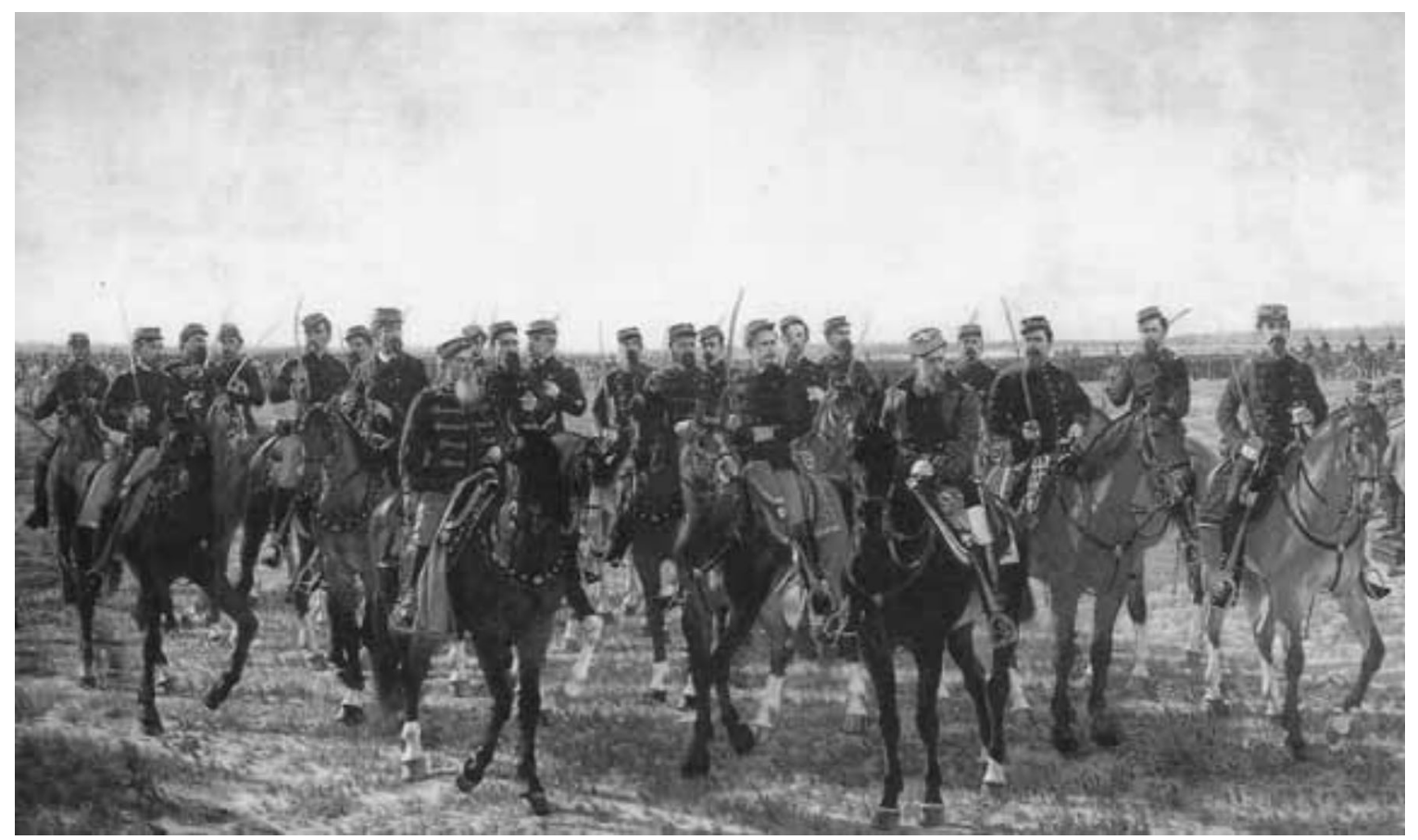

aquéllos que han sido sometidos, se comienza a tener una mirada condescendiente, transformándose en ocasiones en objetos coleccionables por su "ingrediente exótico".

La modernidad a la que la élite dirigente había lanzado a la Argentina entendía que debía superar esa etapa de "salvajismo" para lograr una Nación culta y progresista, y la imagen contribuyó a la legitimación de ese proyecto. ¿Cómo la Paris sudamericana iba a estar rodeada de indígenas salvajes que atacaban la seguridad de las personas y a la misma Iglesia? Esto se denunciaba, aún con montajes fotográficos", y por otro lado se mostraba ese "acuerdo" con los "otros" a través de las imágenes del encuentro y la convivencia con el indígena, soslayando la destrucción $y$ el genocidio que sufrieron en este contexto los pueblos originarios.

El Estado argentino parecía haberse consolidado institucionalmente, pero la Nación no acordaba aún referentes claros de identidad. El gaucho continuaba siendo, en este contexto, el personaje nuclear de los discursos literarios y visuales, el depositario de la identidad argentina. Aún la élite dirigente miraba en forma aprobatoria a este personaje -también exotizado- y la pintura recurría una y otra vez a su representación. La fotografía de fines del siglo XIX y principios del XX también hizo hincapié en la documentación de la vida gauchesca: uno de los proyectos fotográficos significativos en este sentido ha sido la ilustración fotográfica ${ }^{12}$ del Martín Fierro de José Hernández que realizaron los miembros de la Sociedad Fotográfica Argentina de Aficionados ${ }^{13}$, cuyos miembros pertenecían a le élite porteña: las composiciones construidas para este proyecto finalmente no fueron publicadas, probablemente por el poco convencimiento que las escenas podian transmitir sobre la vida gauchesca, pero el mismo sirvió de base para el primer film exitoso argentino, Nobleza Gaucha (1915) ${ }^{14}$. Sin embargo, algunas fotografías de la Sociedad Fotográfica, que parecieran reeditar -ahora fotográficamente- el ideario gauchesco de Pallière realizado sesenta años antes, fueron difundidas ampliamente a través de postales en las primera década del siglo $\mathrm{XX}$, al igual que imágenes de este tenor realizadas previamente por Esteban Gonnet, Benito Pannunzi, Christiano Junior, Samuel Boote y por contem- 
poráneos a la Sociedad, como Harry Grant Olds, Samuel Rimathé, José de Iriondo, entre otros. Todas ellas pretenden transmitir la nobleza de la vida gaucha, imágenes que se complementan con el otro polo de la iconografía fotográfica de la época, las imágenes progresistas de la vida ciudadana. Ciudad y campo aparecen, por consiguiente, como dos polos que se integran en una nacionalidad que admite a "todos" y que legitima positivamente al gaucho rural como al inmigrante urbano.

Estas representaciones que seguian un fin pedagógico se complementaban con un fuerte accionar de un grupo de artistas, entre los que sobresale Eduardo Schiaffino, por desarrollar el gusto estético por las obras del arte universal, convencidos de que el arte era un elemento indispensable para la consolidación de la Nación y el progreso de la "civilización"15. De tal forma, era necesario que los artistas crearan obras que representaran a una nación civilizada -depositando la mirada en el arte académico europeo-, pero también que se contara con modelos para educar el gusto artístico en el público. Estos pintores "pretendian 'educar el buen gusto', 'inculcar ideales', 'enseñar verdades que dicta el espíritu', erradicar no sólo la ignorancia y el 'mal gusto' de las masas 'inertes' y de los nuevos burgueses materialistas sino también los hábitos violentos de un pasado 'bárbaro'" (Malosetti Costa, 2001, 55).

Ello revela que para estos artistas de la generación del '80, la identidad radicaba no solamente en el contenido de las obras, sino también en una estética que emulara la producida en las "naciones civilizadas", poniendo el foco de la mirada particularmente en París. El componente pedagógico tenía, por consiguiente, un doble objetivo.

\section{IMÁGENES POR DOQUIER: LOS IMAGINARIOS DEL Centenario}

El advenimiento de la conmemoración del Centenario de Mayo en 1910 en un clima de fervor patriótico, constituyó el escenario propicio para el planteamiento de programas iconográficos desde el nacionalismo oficial y para la profusión de imágenes desde diversos intereses y presupuestos, como así también para las discusiones sobre la cuestión del arte nacional ${ }^{16}$ que constituyen el corolario de acciones y percepciones sobre el tema de la identidad y la nacionalidad que se dieron a lo largo de la generación del ' 80.

Si bien esta plétora de imágenes se dio principalmente en Buenos Aires, que debía ser mostrada al mundo como la "Gran capital", las fiestas se reprodujeron en menor escala en todo el país y el programa iconográfico y editorial llegó a los distintos puntos de la Argentina. La literatura nacionalista de la época también se encuentra inmersa en estas discusiones, y al igual que el imaginario oficial del Centenario los discursos visuales, literarios e históricos se prolongarán incluso durante las décadas siguientes. Es necesario destacar la publicación en estos años de obras fundantes del nacionalismo cultural como "La restauración nacionalista" de Ricardo Rojas ${ }^{17}$. Y el naciente cine mudo también intervino en la cuestión de la nacionalidad: el primer film argumental trataba justamente "La Revolución de Mayo" (1909) ${ }^{18}$ y su discurso era coherente con la difusión del mensaje historicista y pedagógico que el Estado Nacional también difundirá a través de otros medios.

La imagen inundó diversos ámbitos de la vida social, cultural y educativa. El Estado se ocupó de ello: desde los textos escolares ${ }^{19}$, las revistas ilustradas, los álbumes conmemorativos, los almanaques, hasta las series postales (fig. 3) y las estampillas -con los miembros de la Primera Junta de Gobierno Patrio, los héroes militares nacionales o el Cabildo de Buenos Aires, reproducciones del Cabildo, la Casa de Tucumán, la Pirámide de Mayo, en ocasiones junto a la representación de la República-, sirvieron de soporte para consolidar la imagen histórica que desde el nacionalismo oficial se proyectó. La publicidad también se hizo eco, reproduciendo varios de los símbolos citados a un público masivo.

El historicismo nacionalista al que el Estado se adhirió buscó por un lado reeditar imágenes de la historia patria, de sus héroes y personajes célebres y por otro, visibilizar el progreso modernizador de la Argentina a través de las imágenes urbanas y los hitos arquitectónicos de Buenos Aires. En cuanto a la historia nacional, el repertorio de imágenes que se difundieron procedian de las copias de óleos del Cabildo y de la Plaza de mayo que se habían producido en el siglo XIX, como el óleo de Juan Manuel Blanes del Cabildo Abierto del 22 de mayo de 1810 (Museo Histórico Nacional, ca. 1876), como nuevas representa- 
3. Tarjeta postal del General Cornelio Saavedra, Presidente de la Primera Junta de Gobierno de 1810, rodeado de figuras alegóricas. 1910.

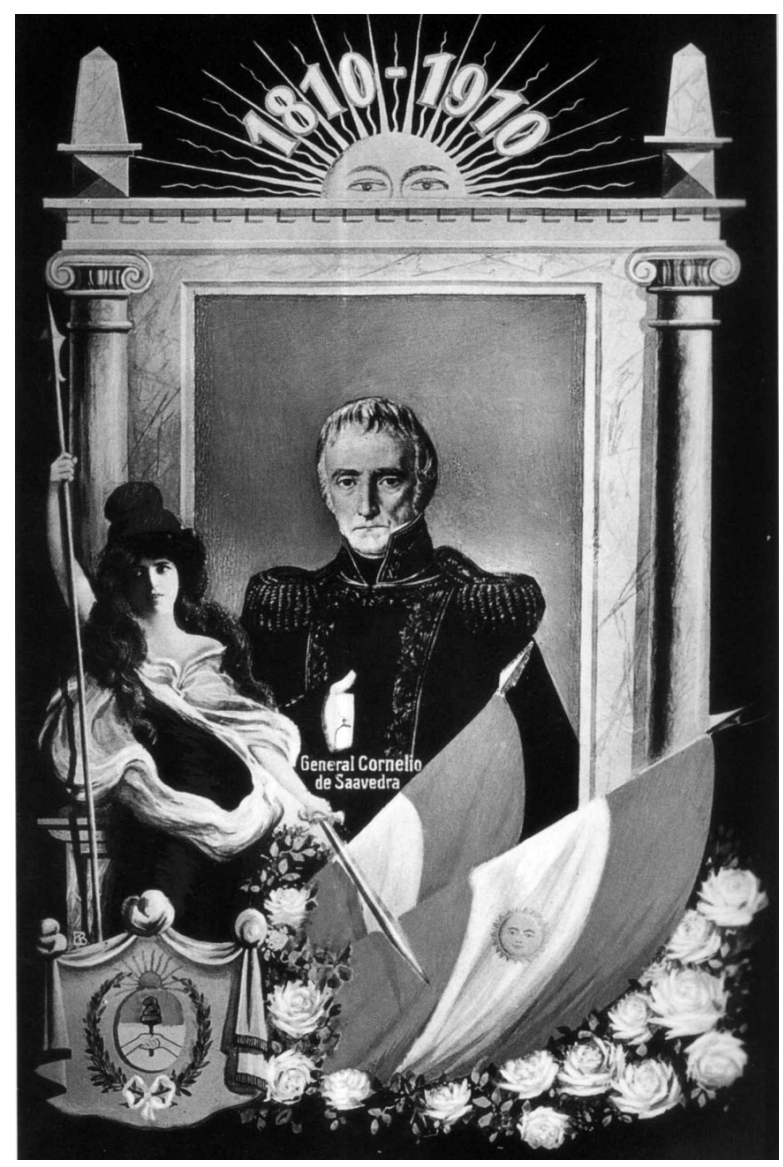

ciones que conmemoraban esta revolución, entre ellos $E I$ Cabildo Abierto del 22 de Mayo de 1810 (Museo Histórico Nacional, 1909) de Pedro Subercaseaux ${ }^{20}$.

En cuanto al progreso urbanístico, además de su presencia en las publicaciones oficiales, la fotografía comercial también se adhirió a la difusión de las mismas: en vísperas del Centenario, las principales casas editoras de postales de Buenos Aires dedicaron series a las principales ciudades del pais, reflejando aquellos espacios y edificios que representaban el afán modernizador con que la Argentina pretendía mostrarse al mundo. Muchas de estas fotografías fueron a su vez las que ilustraron los álbumes del Centenario, donde los datos demográficos y productivos eran corroborados con las imágenes del progreso urbano y arquitectónico del país.

Por otro lado, imágenes alegóricas incluidas en éstas y otras publicaciones muestran el reencuentro con España: entre ellas, la simbolización de ambos estados a través de la Libertad-República con gorro frigio que se encuentra con la Monarquía con la corona de Castilla. Por un lado, las estampillas oficiales reiteraban la iconografía revolucionaria producto de Mayo, y por otro, la clase política se adhiere también a esta nueva etapa de reencuentro entre España y Argentina. La representación alegórica de la República será uno de los símbolos presentes en publicaciones de amplia circulación, en los Álbumes como en libros de historia argentina. Ejemplos de ello son las láminas de Eusevi publicadas en el Album del Centenario (Rosso ed., 1910), donde la República aparece simbolizada con diversos atributos consecuentes con la ideología de la clase hegemónica y el Estado Nacional: la República como diosa de las Artes, la República como diosa de la Agricultura y Ganadería y la República como heredera de los hechos de Mayo y custodia de las leyes (donde la imagen del Cabildo de Buenos Aires indica a esta ciudad como la depositaria de esa herencia). Economía agroexportadora, desarrollo cultural y artístico y legitimidad institucional sintetizan este ideario. Otra publicación, la Historia Argentina (Cánepa, 1918) presenta una lámina de Francisco Fortuny donde la República resume dos de los aspectos antes señalados: la custodia de las leyes y el arte.

Complementariamente, en torno al Centenario se dio una profunda discusión sobre el arte nacional, que se orientaba principalmente a la cuestión temática: artistas como Malharro y Mas y Pí señalaban al paisaje, los tipos regionales y populares y sus costumbres contemporáneas -y no pretéritas-, como la temática en la que se debía buscar "lo auténtico" del arte nacional. De esta manera, muchos de los artistas que estaban radicados en Buenos Aires, van a trasladarse a vivir al interior de la Argentina en esa búsqueda de esa "fuente creadora" según conceptos de Más y Pí.

Por lo tanto, el "arte nacional" ponía su énfasis en el contenido y no la forma, donde el paisaje no es un mero género sino que "el paisaje se convirtió... en el refugio del alma nacional, punto de partida para la consolidación de una identidad propia..." (Gutiérrez Viñuales, 2000, 229). 


\section{La "estatuomanía" del Centenario}

Dentro de la gran profusión de imágenes en torno al Centenario, los monumentos conmemorativos tuvieron un peso de gran importancia en la conformación de los imaginarios nacionales. En el caso argentino, luego de los hitos monumentales post revolucionarios (Pirámide de Mayo) la representación escultórica del héroe comenzó con los monumentos a los padres de la patria antes mencionados, que fueron reproduciéndose con igual iconografía en ciudades del interior. A fines del siglo XIX, otros monumentos emplazados en la ciudad de Buenos Aires convocaron la atención de la prensa y de la crítica, como el monumento a Sarmiento realizado por Auguste Rodin (1900) ${ }^{21}$.

El Centenario se convirtió en el escenario de una fiebre de la estatuaria, ya que diversos sectores de la sociedad argentina entendieron a las obras conmemorativas como símbolos válidos y fehacientes para afirmar el poder grupal en la misma. Las diferentes colectividades de inmigrantes plantearon monumentos para homenajear el Centenario, generándose "... una especie de lucha internacional -cuyos principales actores eran Francia, España, Italia y Alemania- interesados en ocupar un lugar de preeminencia y en mostrarse, a través de estas representaciones, con un perfil bien diferenciado" (Aguerre, 2005, 51).

Lo cierto es que el Estado Nacional y el Municipio de Buenos Aires encararon una importante y sostenida política monumental: el primero a través de las propuestas de la Comisión Nacional del Centenario y el segundo, a través de una Comisión Municipal integrada por personajes ilustres porteños.

De tal forma, el imaginario se debatía entre la representación de los próceres de mayo de 1810 (Paso, Moreno y Vieytes fueron los primeros encargos de la Comisión Municipal), mientras que desde la Comisión Nacional, la ley del Centenario preveía erigir en Buenos Aires monumentos a la Revolución de Mayo, a la Asamblea del Año XIII, al Ejército de los Andes, a Alvear, Brown, Moreno, Rivadavia y Pueyrredón. Asimismo, se realizó un concurso internacional para el Monumento a la Independencia -que reemplazaría a la Pirámide y que nunca se realizó ${ }^{22}$ - en la Plaza de Mayo (1908-1910) y el Monumento conmemorativo a la Creación de la Bandera Nacional en Rosario
(1872-1957), los que son demostrativos de la fértil imaginación y la fecunda labia que justificaba la adopción de proyectos generalmente bastante ortodoxos en esquemas academicistas, donde tenía más peso la identificación con el estereotipo icónico y la potencial monumentalidad que la recreación de una propuesta simbólica pero de un contenido histórico preciso (Gutiérrez y Gutiérrez Viñuales, 2006). Estas "soluciones estéticas" fueron comunes en la fiebre monumental de la época, donde lo importante era la realización de hitos conmemorativos que implicaban reivindicaciones históricas pero, contradictoriamente, se encontraban vaciados de historicidad.

Este historicismo se conjugó con monumentos simbólicos como "A la Carta Magna y las cuatro regiones argentinas", ofrecida por los residentes españoles y realizada por Agustín Querol, proyecto iniciado en 1908 pero inaugurado recién en $1927^{23}$.

Otro monumento de importancia en la construcción de la nacionalidad visual fue el Monumento a los españoles (fig. 4): el mismo se justifica por el nuevo momento de las relaciones entre Argentina y España, ya que la actitud respecto a lo español comenzó a cambiar en el discurso oficial argentino a fines del siglo XIX como consecuencia de la gran cantidad de inmigrantes españoles arribados ${ }^{24}$. En este contexto es que el gobierno nacional había previsto en la ley del Centenario la realización de un monumento a España, constituyendo éste el único reconocimiento iconográfico que el Estado hiciera a una nación extranjera. Ello implicaba que la República estaba consolidada y que España ya no era visibilizada como un enemigo sino como la Madre Patria a la que había que rendir homenaje. Nuevamente el proyecto del escultor Arturo Dresco provocó discusiones en referencia a los símbolos presentes en su programa iconográfico: tres ejes temáticos sintetizaban el mismo, planteados en torno al descubrimiento, la conquista y el virreinato, a la vez que un grupo escultórico que representaba a Colón arrodillado a los pies de Isabel la Católica organizaba los ejes mencionados. Coronaba toda la obra, en un estrato superior del conjunto monumental, una representación de España en el trono sujetando a una joven República Argentina. Lógicamente que la Comisión no aceptó este coronamiento, insistiendo en afirmar la condición igualitaria de ambos paises en la representación. "Parecía necesario, en 1914, proclamar claramente que la Argentina, si bien reconocía explícitamente la función de 


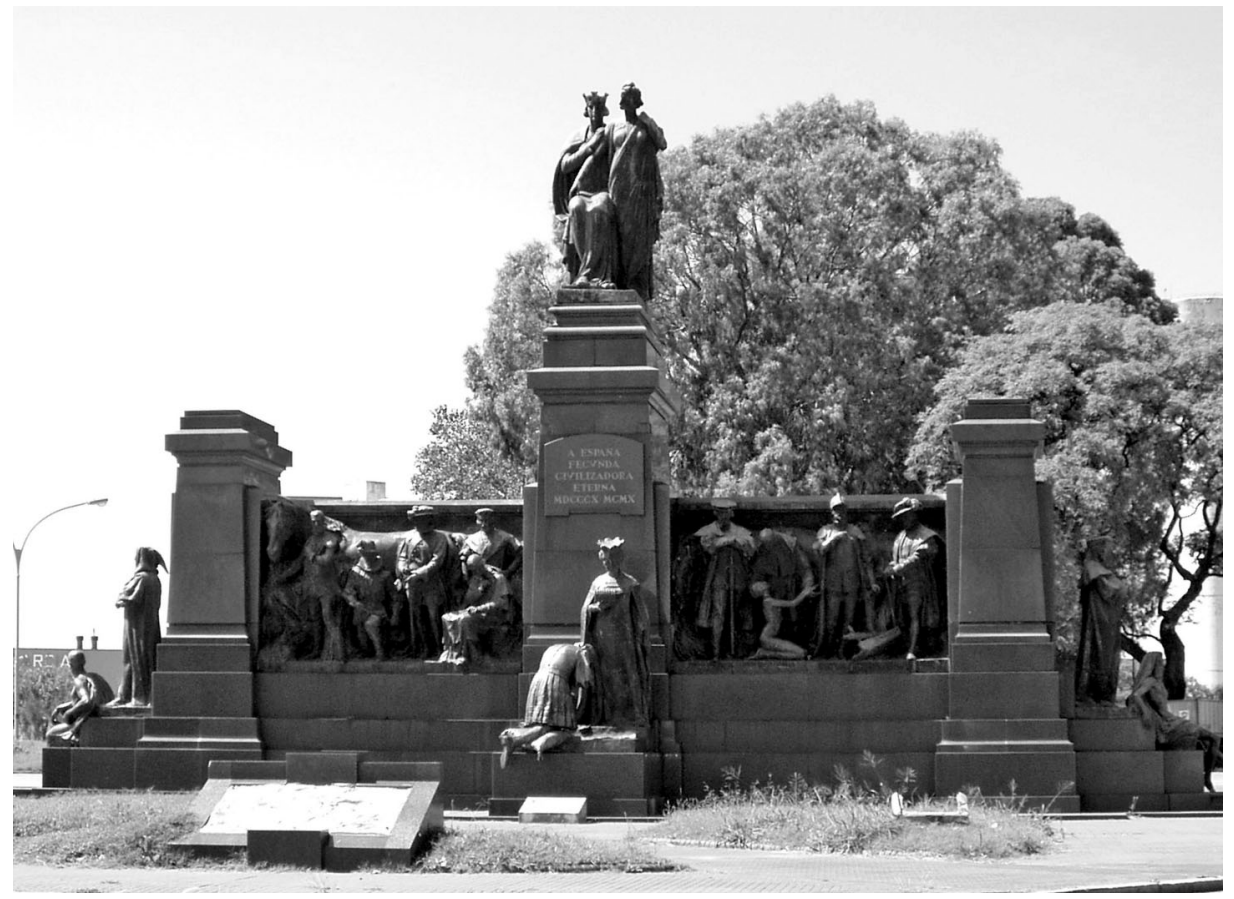

España en su génesis y desarrollo como nación, no habría de permanecer indefinidamente en un rol de minoría de edad. Las imágenes debían coincidir plenamente y representar esta postura" (Aguerre, 2005, 71).

\section{LA TENSIÓN ENTRE TRADICIÓN Y MODERNIDAD EN LOS IMAgINARIOS DE NACIÓN}

Después del aluvión inmigratorio resultaba difícil encontrar una representación del "pueblo argentino" que sintetizara el ideal del "ser nacional", lo que pareció una tarea conflictiva entre las manifestaciones visuales: "nación", "cosmopolitismo" y "nacionalismo" adquieren entonces una nueva reformulación, en ocasiones contradictoria, pero que en definitiva revelan las diversas caras con que el tema se presenta en el prisma social, cultural y étnico. Tradición y modernidad serán dos de los tópicos en cuestión en el arte nacional ${ }^{25}$, y los cruces y pliegues que transitan ponen de manifiesto la cuestión de la identidad como un tema inconcluso, una discusión abierta, y la vez la necesidad de construirla desde lo diverso y contradictorio más que desde lo hegemónico y homogéneo.

En las décadas de 1920 y 1930 se reeditó por un lado un costumbrismo nativista orientado tanto a la representación del indígena -que ya estaba "sometido" y por lo tanto se le mira condescendientemente- como del gaucho. Por otro lado, la modernidad radicada en el cosmopolitismo de la gran ciudad y el apego a lenguajes vanguardistas europeos.

Desde la adopción de temas tradicionales, muchos artistas toman los paisajes y tipos rurales contemporáneos -siguiendo las propuestas de Malharro y Más y $\mathrm{Pi}$-, como Alfredo Gramajo Gutiérrez, Fernando Fader, Carlos Giambiagi; otros como Cesáreo Bernaldo de Quirós representa no sólo las costumbres del gaucho de su época sino que remite al ideario decimonónico sobre el papel de este personaje en la vida política y social de la Argentina.

El primero de los citados, Gramajo Gutiérrez, procedente del noroeste argentino, presenta las costumbres norte- 
ñas desde un realismo ingenuo, apuntando a mostrar la mentalidad religioso-supersticiosa de las tradiciones de su tierra. Su obra, difundida también a través de ilustraciones de revistas y libros ${ }^{26}$, encontró un camino propio en la representación de temas costumbristas.

El indigenismo plástico, de gran difusión en esta época en países como Bolivia, Perú, Ecuador o México, se hace presente también en la Argentina no sólo en la obra de Gramajo, sino también de artistas de la talla de Jorge Bermúdez, José Antonio Terry y, posteriormente, Francisco Ramoneda. Gómez Cornet, cuyo ojo "educado en Europa" y considerado un "pintor de almas", también aborda los campesinos indígenas santiagueños.

La importancia de lo nativo en los Salones también se enmarca en la cuestión de la identidad nacional y revela la importancia del tema tanto en pintura como en escultura. Penhos señala que dentro de las obras nativistas presentadas en el Salón Nacional entre 1911 y 1945, sobresalen las que refieren a indígenas o mestizos del noroeste argentino, las "cholas" y "coyas" -a excepción de obras de los escultores Perlotti y Puyau-, los que son representados con un perfil pintoresquista y decorativo, sin manifestar un interés por la situación de estos grupos en el presente de su representación (Penhos, 1993, 28-29). Ello se vincula con el pensamiento de Rojas al que hemos hecho alusión previamente: el indígena es considerado un "antepasado espiritual", referente de lo telúrico y por ello parte de una identidad nacional.

A la manera de fantasma recurrente del imaginario nacional, el gaucho reaparece como símbolo de la identidad nacional en las décadas mencionadas: es el "tipo social" por excelencia en el imaginario argentino. El mismo Bermúdez recurre a él, pero será Quirós, enfrentado a la "modernidad" entendida como el cosmopolitismo moderno, uno de los máximos exponentes de temática gauchesca de la época, quien busca la afirmación de la identidad a través de una inclinación hacia lo épico de la vida gauchesca, utilizando para ello un lenguaje naturalista. En su serie "Los gauchos" el artista glorifica y mistifica el "alma criolla" entendida como el numen del "ser nacional", reactualizando de esta forma ciertos mitos románticos del siglo XIX.

Otro referente gauchesco desde fines de la década de 1920 fue Florencio Molina Campos, cuya obra costumbrista y caricaturesca popularizó la vida y costumbres gauchescas a través de su difusión en los Almanaques de Alpargatas y desde 1942, en su asesoramiento a Walt Disney para la filmación de "El gaucho reidor", "Goofy se hace gaucho" y "Saludos amigos".

En escultura, el artista santafesino radicado en el Chaco Juan de Dios Mena se presenta como un caso original en esta disciplina; sus pequeñas tallas de madera policromada que conforman una galería de tipos sociales del mundo rural y de los pequeños poblados, se apartan de la escultura consagrada en Buenos Aires, de ahí que su obra fuera vista por la crítica de esa ciudad como una obra artesanal ${ }^{27}$. El mundo criollo, los vicios, los bailes, payadores, guitarreros, parejas bailando diversas fiestas camperas fueron tratados tanto por Molina Campos como por Mena desde una perspectiva risueña pero condescendiente con la vida gauchesca (Giordano, 2005). Otra producción, como tantas del interior argentino, que por mucho tiempo permaneció también en los "bordes" del arte consagrado.

\section{Conclusiones}

Tal como se desprende de lo expuesto, la conformación de imaginarios de Nación vinculado a la configuración de una identidad nacional que las artes visuales de la Argentina del siglo XIX y parte del XX han pretendido consolidar, atravesó un extenso, complejo $-y$ en ocasiones confuso- proceso de búsquedas y transformaciones.

Se inició con los festejos de las fiestas cívicas y la delineación de los héores nacionales, que se fueron (re)delineando a lo largo del siglo XIX, para ampliarse este panteón con los "notables" y las "celebridades", retratos vinculados a un discurso historicista y positivista. Ello se complementó con la representación de los hechos históricos sobresalientes de la Revolución de Mayo y la Independencia Argentina, que aún se retomaron en los momentos de mayor efervescencia del discurso patriótico de la década de 1910.

Paralelamente a este imaginario con fuerte apego a la memoria histórica, en el siglo XIX y luego de la época de la anarquía, el rosismo y la lucha entre federales y unitarios, se buscó representar un ideal de unificación territorial, recurriendo al paisaje pampeano como símbolo de un na- 
cionalismo natural y a las figuras del indígena y el gaucho como los personajes de ese paisaje. La pampa, territorio infinito e inconmensurable, fue el escenario que eligieron los artistas para imaginar numerosas escenas cargadas de romanticismo; pero a la vez, esa pampa fue también el "desierto", el espacio que el poder político quiso conquistar para concluir con el "problema indígena". Aquí el gaucho representó un papel indeterminado y en ocasiones contradictorio, si nos atenemos a otras fuentes. Este personaje, que fue una construcción simbólica recurrente en varios siglos de la historia argentina, adoptó en estos imaginarios visuales un perfil de héroe romántico en la pintura del siglo XIX, de "tipo argentino" o esencia de "lo argentino" a fines del siglo XIX y parte del XX. Imagen contrapuesta a aquélla a la que incluso se adhirieron personajes de la élite porteña, cuando se produjeron las persecuciones de gauchos por parte de terratenientes bonaerenses y las permanentes quejas por este personaje libre e indómito (que por cierto se asemejaba más a un campesino sin tierras que al ideal de un hombre libre apegado a lo telúrico).

De esta forma, este imaginario visual se concentró solamente en la imagen del "gaucho bueno" en una relación idílica con el mundo rural, soslayando la imagen del "gaucho malo" o pernicioso para el progreso argentino que existiera en otros discursos.

Por otro lado, el contraste campo-ciudad constituyó una fina línea de la tradición enraizada en la pintura gauchesca-criollista y en la cultura popular argentina. Línea a partir de la cual también se ha tejido la historia social del recuerdo del "ser argentino" a través del imaginario visual. La construcción de un mundo rural gauchesco supuso así, un límite con la configuración de una Buenos Aires "civilizada", representada por una élite ilustrada que miró condescendiente e idilicamente a ese mundo rural.

La dialéctica campo-ciudad, estuvo latente en numerosos discursos visuales de los dos siglos analizados, dando lugar asimismo a la tensión entre tradición-modernidad, tanto en lo temático como en lo formal, y desplegando no obstante su mirada hacia el exterior para nutrirse de los lenguajes vanguardistas europeos.

A la vez, las conmemoraciones y los aniversarios han actuado de puntos de enclave o contextos donde se han puesto de manifiesto visualmente los "balances" históricos o donde sectores más amplios de la sociedad buscaron y consagraron sus referentes identitarios. En tal sentido, hemos podido apreciar la "contienda de imágenes" producidas en torno al Centenario, los enfrentamientos entre paises y entre colectividades para participar de las producciones artísticas, pero también la consolidación de determinados símbolos, y los modos en que "el arte nacional" emergió en ciertos contextos con mayor fuerza que en otros.

Así, en aquellos momentos claves donde la cuestión de la identidad nacional inundó diversos estratos de la vida cívico-social, se advierten hoy indicadores de institucionalización que de una u otra forma pretendieron forjar un imaginario hegemónico, centrado en lo producido y consagrado en Buenos Aires, con poca o ninguna participación de producciones o referentes regionales.

Distribuyendo roles, funciones y posiciones sociales, expresando e imponiendo creencias comunes que determinaron algunos modelos formadores de la "identidad nacional" (Backzco, 1984), las artes visuales de la Argentina del siglo XIX y parte del XX, trataron de contar la historia de esta búsqueda y conformación identitaria, intentaron rehacer los hechos y situaciones consideradas "significativas" desde varias experiencias. Para ello se valieron de diferentes signos, marcas y huellas de nacionalidad que dieron cuerpo y materialidad a diversos imaginarios.

Sólo algunos de ellos se han impuesto y han sobrevivido a esta búsqueda que en muchos casos supuso fuertes luchas, tensiones y contradicciones dentro del prisma social, étnico, artístico-cultural y político, pero cada uno de ellos en su especificidad y complejidad han -en palabras de Baczko (1984)- labrado la memoria como fuente histórica y como historia social del recuerdo. Han tejido una red de relaciones imagéticas que actuaron como memoria afectivo-social de la cultura argentina, como substrato ideológico mantenido por dicha comunidad a lo largo de su historia, poniendo de manifiesto que la "identidad nacional" expresada visualmente, no implica una única, total y acabada manera de "ser argentino", sino un continuo y permanente proceso de identificaciones heterogéneas y disímiles, pero complementarias. 


\section{NOTAS}

1 El hecho de pensar e imaginar el desierto constituyó una de las tantas prácticas que operaron en la sociedad, la ciencia y la política argentina para justificar la necesidad de poblar ese espacio "vacío" (de "civilización"): este pensar e imaginar legitimó entonces las prácticas para cristianizar o luchar contra los pobladores de ese desierto -los indígenas-, y su ocupación progresiva con inmigrantes. Esto sucedió en primer término con la ocupación del "desierto sur" (Pampa y Patagonia) y luego con el "desierto norte" (región chaqueña). Esta construcción fue paulatina a lo largo del siglo XIX.

2 Algunos ejemplos sobresalientes de imaginería popular son "El buen ladrón", "El mal ladrón" y "San Lorenzo" que se encuentran en el Museo de la Basilica de Itatí (Corrientes), además de hallarse piezas dispersas entre colecciones particulares y de diversas capillas y municipios de esta provincia.

3 Pensemos por ejemplo que a Núñez de Ibarra, a quien hemos hecho referencia por los primeros retratos de San Martín y Belgrano, la historiografía lo ha rescatado por haber sido el pionero en representar a los héroes de la naciente nación, pero no se ha estudiado su trabajo como platero, que era lo que desarrollaba en su provincia, Corrientes.

4 Amigo analiza la Galería de héroes retratados en el diario mitrista Los Debates, obras realizadas mayoritariamente por el pintor, grabador y litógrafo Narcise Desmadryl, que eran acompañadas en su publicación por artículos o ensayos históricos sobre la celebridad retratada realizados por miembros relevantes de la intelectualidad argentina como Sarmiento, Mitre o Gutiérrez (Amigob, 1999).
5 El triunfo de Buenos Aires en la Batalla de Pavón (1862) contra la Confederación Argentina significó el triunfo de la élite dirigente del Estado de Buenos Aires, entre los que se encontraban varios de los políticos e intelectuales que señalamos como impulsores del panteón de celebridades. De ahi que fueran éstas las que se extenderian al interior del país.

6 La generación del ochenta (18801916), impuso en la Argentina un proyecto de ideas liberales, que pretendia dejar atrás un pasado considerado "bárbaro", para lo cual había que ocupar firmemente el territorio argentino y poblarlo con inmigrantes de origen europeo. La lucha armada contra el indígena fue parte de este proyecto de ocupar el "desierto" poblado por el "bárbaro" para transformarlo en tierra de "civilización".

7 Esta fotografía fue obtenida por Morelli, se encuentra en el Álbum Fotográfico de Encina y Moreno de 1883 del Museo Roca, es conocida como "Los caciques de Ñorquin" y representa al Regimiento n. 3.

8 El imaginario que se creó de la campaña de Buenos Aires (la pampa) para le época post colonial era la de un vasto territorio cruzado por grandes manadas de ganado vacuno, dominado por un selecto grupo de terratenientes que monopolizaba la tierra, enfrentados a un grupo de pobladores pobres, caracterizados como "gauchos", quienes eran poco proclives al trabajo continuo, que deambulaban de pulpería en pulpería, al territorio indigena y cada tanto trabajaban en alguna estancia.

9 Al respecto, en julio de 2007 se presentó un proyecto en la Cámara de Diputados de la Nación para suprimir esa imagen y reemplazarla por una representación de las Islas Malvinas 
(Expediente n. ${ }^{\circ}$ 3598-D-2007 presentado por José Mongeló).

10 Un disco de tangos del grupo "Malón" de principios de la década del setenta, integrado por el conocido artista argentino Juan Carlos Cáceres, llevaba ilustrada la tapa con "La vuelta del Malón".

11 Nos referimos particularmente a una imagen obtenida por el fotógrafo Theo Fumière y difundida en formato postal en las primeras décadas del siglo XX, cuyo epígrafe decía "Indios del Chaco. Tribu en armas", pero al prestar atención nos encontramos con esos guerreros son en su mayoría niños que fueron hechos posar con lanzas para la toma.

12 Las imágenes fueron obtenidas alrededor de 1890, por Francisco Ayerza con la colaboración de Leonardo Pereyra, propietario de la Estancia San Juan (hoy Parque Pereyra Iraola, La Plata). Los negativos y copias se encuentran en la Academia Nacional de Bellas Artes (Buenos Aires).

13 Esta sociedad se creó en Buenos Aires en 1889, por iniciativa de un grupo de interesados de la alta burguesía porteña aficionados a la fotografía, con Francisco "Paco" Ayerza a la cabeza, y retomando acciones similares realizadas en Montevideo y Europa. Realizaron una intensa producción abarca desde 1890 a 1910, realizando concursos y editando sus imágenes en postales.

14 Este film aborda la epopeya de un gaucho bonachón que ayudado por un "tano cocoliche" viaja a Buenos Aires para rescatar a su paisana que había sido raptada por el estanciero malvado "Aquí la alianza entre el gaucho y el italiano puede leerse como una expresión muy directa de la conformación del conglomerado criollo-inmigratorio y de la conciencia de esta nueva identidad: juntos en la ficción vencen al poderoso estanciero" (Sarti y Rodríguez Otero, 42-43).

15 Este discurso de fuerte impronta positivista tuvo una amplia difusión periodística en el último cuarto del siglo XIX. A partir de la Crisis argentina de 1890, el papel del arte -el que para Schiaffino era tan imprescindible como las actividades científicas- en el "progreso" de la Nación y en el proceso civilizador mostró su fragilidad y el discurso atenuó sus afirmaciones, pero mantuvo los fundamentos.

16 Un interesante trabajo sobre la problemática del arte nacional en relación a la Exposición Internacional de Arte del Centenario de 1910 se encuentra en Muñoz, 1999, 166-177.

17 Este nacionalismo cultural surge como una necesidad de rescatar las tradiciones frente al cosmopolitismo que implicó la inmigración. La revalorización de la vida rural (criollismo) e incluso del indígena (a quien se lo seguía viendo como un elemento negativo), fueron algunos de sus puntos principales. Ricardo Rojas consideraba que la herencia de los pueblos indígenas era uno de los elementos que formaban "la constitución espiritual del pueblo argentino", junto a la herencia española y la inmigración, elementos que debian ser homogeneizados por una educación que dote al conjunto de una conciencia histórica.

18 El film estuvo dirigido por el italiano Mario Gallo y producido por el español Ajuria.

19 "La función educadora de la estética era una preocupación extendida entre los intelectuales de principios de siglo" (Amigo, 1999a, 173).

20 El primer director del Museo Histórico Nacional encargó a Subercaseaux en 1908 cuatro obras de género histórico en vistas a la Exposición Internacional del Centenario, siendo la mencionada una de ellas, junto a "La noche del 20 de mayo en casa de Rodríguez Peña", "La Junta Gubernativa del 25 de mayo de 1810" y "Mariano Moreno en su mesa de trabajo" (Gutiérrez y Gutiérrez Viñuales, 2006).

21 Véase Constantin, 1995 y Aguerre, 1999, 143-156.

22 Sobre la competencia internacional para realizar este monumento, véase Piccioni, 1997.

23 La mayoría de los monumentos que fueron proyectados en la época del Centenario se concretaron posteriormente.

24 El asentamiento de miles de inmigrantes españoles desde fines del siglo XIX hacía incoherente la mirada negativa hacia la "raza española" como muchos textos positivistas mencionaban. El establecimiento de un nuevo estatus en la relación España-Argentina se dio en numerosos campos, tanto político-institucionales como sociales y culturales. La confraternidad, la unión y el apoyo mutuo serán los signos visibles de esta nueva relación entre países.

$25 \mathrm{El}$ tema ha sido objeto de amplio análisis en la historiografía del arte argentino. Nosotros plantearemos algunas puntas de la cuestión en relación a la cuestión de la construcción de un imaginario de Nación y de la configuración de una identidad nacional.

26 Fue ilustrador permanente de la Revista "Riel y Fomento", también de algunos números de la revista de la joven generación "Proa" y de varios libros, entre ellos "El País de la Selva" de Ricardo Rojas.

27 La revista Sur señala a propósito de una exposición de Mena en Buenos Aires en 1936 que "... En sus esculturas no hay raquitismo plástico sino 
más bien material tosco no esculpido aún.... Por esa sinceridad de su proceder, este excelente artesano revela enseguida el procedimiento primitivo de su trabajo que se limita a la observación del 'tipo' que quiere representar, sin preocupaciones de ritmos de composición" (Sur n. 24, 1936).

\section{BIBLIOGRAFÍA}

Aguerre, Marina (1999): "Buenos Aires y sus monumentos; la presencia francesa", en Gutman, Margarita y Thomas Reese (eds.), Buenos Aires, 1910; El imaginario para una gran capital, Buenos Aires, Eudeba, pp. 143-156.

Aguerre, Marina (2005): "Lazos de bronce y mármol. España y la Argentina en los monumentos de la ciudad de Buenos Aires," en Aznar, Yayo y Weschler, Diana (comps.): La memoria compartida. España y la Argentina en la construcción de un imaginario cultural (1898-1950)، Buenos Aires, Paidós, pp. 47-76.

Amigo, Roberto (1999a): "Imágenes de la historia en el Centenario: nacionalismo e hispanidad", en Gutman, Margarita y Thomas Reese (eds.), cit., pp. 171-195.

Amigo, Roberto (1999b): "Imágenes de la historia y discurso político en el Estado de Buenos Aires (1852-1862)", en Amigo, Roberto y Patricia Doso: Arte Argentino de los Siglos XVIII y/o XIX, Buenos Aires, FIAAR, pp. 11-56.

Amigo, Roberto (2003): "La tradición olvidada. Notas sobre la pintura regional rioplatense", II Congreso Internacional de Teoría e Historia de las Artes Discutir el Canon, Buenos Aires, CAIA, pp. 273-282.

Anderson, Benedict (1991): Imagined Communities, Reflection on the origin and spread of Nationalism, Londres, Verso.
Baczko, Bronislaw (1984): Les imaginaires sociaux. Mémoire et espoirs collectifs, París, Payot.

Cánepa, Carlos (1918): La Historia Argentina. Desde el Descubrimiento de América hasta la actualidad, Buenos Aires, Cabaut y Cía.

Constantin, María Teresa (1995): "La Confrontación política como disfuminadora de los límites entre lo público y lo privado. El Sarmiento de Auguste Rodin", VI Jornadas de Teoría e Historia de las Artes El arte entre lo público y lo privado, Buenos Aires, CAIA, pp. 217-227.

Dujovne Ortiz, Alicia (2001): "La mirada desde afuera", en Pintura Argentina: Precursores l: Panorama del período 1810-2000, vol. 16, Buenos Aires, Banco Velox.

Gutiérrez, Ramón y Gutiérrez Viñuales, Rodrigo (2006): América y España, Imágenes para una Historia: independencias e identidad (1805-1925), Madrid, Fundación Mapfre.

Gutiérrez Viñuales, Rodrigo (2000): "La pintura y la escultura en lberoamérica (1800-1925)", en Gutiérrez, Ramón y Rodrigo Gutiérrez Viñuales, Historia del Arte Iberoamericano, Madrid, Lunwerg, pp. 185-238.

Gutiérrez Viñuales, Rodrigo (2003): "El papel de las artes en la construcción de las identidades nacionales en lberoamérica", Historia Mexicana, vol. LIII, n. ${ }^{\circ}$, México, El Colegio de México, pp. 341-390.

Malosetti, Laura (2001): Los primeros modernos. Arte y sociedad en Buenos Aires a fines del siglo XIX, Buenos Aires, Fondo de Cultura Económica.

Malosetti Costa, Laura y Marta Penhos (1991): "Imágenes para el desierto argentino. Apuntes para una iconografía de la pampa", III Jornadas de Teoría e Historia de las Artes Ciudad/campo en las Artes en Argentina y Latinoamérica, Buenos Aires, CAIA.
Munilla Lacasa, María Lía (1995): "Celebrar en Buenos Aires. Fiestas patrias, arte y política entre 1810 y 1830", VI Jornadas de Teoría e Historia de las Artes El arte entre lo público y lo privado, Buenos Aires, CAIA, pp. 154165.

Muñoz, Miguel Ángel (1995): "El arte nacional: un modelo para armar", VI Jornadas de Teoría e Historia de las Artes, cit., pp. 166-177.

Penhos, Marta (1993): "Indios de Salón: aspectos de la presencia de lo nativo en el Salón Nacional (1911-1945)," V Jornadas de Teoria e Historia de las Artes, Arte y Poder, Buenos Aires, CAIA, pp. 23-30.

Pérez Vejo, Tomás (2003): "La construcción de las Naciones como problema historiográfico: el caso del mundo hispánico", Historia Mexicana, vol. LIII, n. ${ }^{\circ}$, México, El Colegio de México, pp. 275-311.

Piccioni, Raúl (1997): "El monumento al Centenario. Un problema de Estado", VII Jornadas de Teoría e Historia de las Artes, Arte y Recepción, Buenos Aires, CAIA, pp. 193-200.

Quijada, Mónica (2003): "¿Hijos de los barcos o diversidad insensibilizada? La articulación de la población indígena en la construcción nacional argentina (siglo XIX)", Historia Mexicana, vol. LIII, n. ${ }^{2}$, México, El Colegio de México, pp. 469-510.

Rosso y Cía (ed.) (1910): Álbum Gráfico de la República Argentina en el Primer Centenario de su Independencia 25 de mayo 1810-1910, Buenos Aires, Imprenta Rosso.

Sarti, Graciela y Rodríguez Otero, Mariano (1993): “¿De qué nos habla nuestro cine mudo? El discurso de la nacionalidad en el cine mudo argentino", V Jornadas de Teoría e Historia de las Artes, Arte y Poder, Buenos Aires, CAIA, pp. 40-47. 